\title{
Characteristics of PPROM in General Hospital Dr. Soetomo Surabaya Period September 2017 to September 2019
}

\author{
Letizia Alessandrini ${ }^{1}$, Budi Wicaksono ${ }^{2}$ \\ ${ }^{1}$ Resident of Obstetric dan Gynecology Devision, Medical Faculty, Airlangga University, General Hospital Dr. \\ Soetomo, Surabaya. \\ ${ }^{2}$ Supervisor of Obstetric dan Gynecology Devision, Medical Faculty, Airlangga University, General Hospital Dr. \\ Soetomo, Surabaya. \\ Corresponding author: dhanuletizia@gmail.com
}

\begin{tabular}{l}
\hline ARTICLE INFO \\
\hline Keywords: \\
PPROM, Perinatal, \\
Morbidity, Mortality.
\end{tabular}

Submission: November 28th, 2020

Review:

December 7 th, 2020

Publish:

July 25th, 2021

\begin{abstract}
Background: Preterm Prelabour Rupture of Membranes (PPROM) is one of the causes of perinatal morbidity and mortality. Objective: To find out the characteristic of PPROM in Dr. Soetomo Hospital in September 2018 to September 2019. Method: A Retrospective Descriptive Study. The data came from the medical records of patients with PPROM who were included in the inclusion criteria. The exclusion criteria is all PPROM cases at Gestational age > 34 weeks. Result: The incidence of PPROM during September 2017 to September 2019 was 6.8\% (175 patients), of which 152 patients included NBC cases and 23 patients with BC cases. Primipara 76 patients and Multipara 99 patients. For gestational age <26 weeks it was $17.1 \%, 26-30$ weeks $29.7 \%$ and 3134 weeks $53.1 \%$. In this study, PPROM was amused $23.6 \%$, underweight $3.1 \%$, HBsAg $7.5 \%$, HIV 7\%, anemia $10.3 \%$, Obesity 5.2\%, Pragestational Diabetes $7.4 \%$, Gestational Diabetes. 2,6\%, preeclampsia 7,9\% and severe preeclampsia $2,2 \%$. The distribution of PPROM patients who received lung maturation was $72 \%$, while the remaining $28 \%$ did not get lung maturation. Type of delivery for PPROM cases was vaginal delivery as much as $60 \%$ while $40 \%$ for cesarean section. Indications for vaginal delivery include fetal distress $25 \%$, abnormal NST $18 \%$, gemeli $17 \%$, BSC $12 \%$, febris $10 \%$, pulmonary edema $5 \%$ and breech presentation $5 \%$. The outcome distribution of PPROM infants born with asphyxia at birth was $87 \%$. Weight of babies

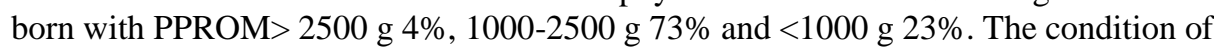
the babies at birth with spontaneous breathing was 36 babies, nasal $\mathrm{O} 2$ was 13 babies and CPAP was 70 babies. The causes of death for preterm KPP babies included RDS 9 babies, Sepsis 4 babies and severe asphyxia 19 babies. The length of NICU care for infants who died with KPP Preterm mothers was <24 hours for 15 babies, 1-3 days 13 babies, 4-7 days 3 babies,> 7 days 3 babies and 5 fetuses were IUFD. 12 patients with PPROM received amnioinfusion while 5 patients with amniopatch, Outcome of infants from conservative PPROM who were treated with amniopatch or amnioinfusion obtained 6 babies died at birth, 8 babies with CPAP breath support, 1 baby with PCV breath support, 1 baby with ventilator and 1 infant spontaneously breathed. A total of 3 babies were outpatient after treatment for a maximum of \pm 25 days. Conclusion: Perinatal care is currently experiencing some rapid progress, but the case of PPROM is still one of the biggest contributors to perinatal morbidity and mortality.
\end{abstract}

\section{Introduction}

Preterm Prelabour Rupture of Membranes (PPROM) is a rupture of the amniotic membrane at $<37$ weeks of gestation (Shailja, 2020). The incidence of PPROM occurs in $3-8 \%$ of pregnancies (Okeke, 2014) and in about $20 \%$ of the causes of preterm labor. This can lead to 
significant perinatal morbidity. PPROM with gestational age less than 34 weeks can be considered to have a conservative therapy. Indication for PPROM's termination is at $<34$ weeks of gestational age. However, if there is an emergency in the fetus, chorioamnionitis, preterm in labor or when the gestational age can exceed $>34$ weeks. (Medina, 2006). There are 3 divided risk factor due to the etiology of the PPROM which are maternal risk factor (such as History of Previous PPROM, Anemia, BMI $<20 \mathrm{~kg} / \mathrm{m} 2$ nutritional deficiencies, low socioeconomic status, too young to get pregnant or U> 35 years, smoke, collagen vascular disorders (ex.SLE)), infant risk factor (such as multiple pregnancy anomalies (malformations, aneuploidies)) and uteroplacental risk factor (for example anomalies in the uterus (uterine septum), placental abruption, history of cervical conization, infection (ex: chorioamnionitis) (Cunningham, 2014).

\section{Purpose}

\section{General Purpose}

Describe the characteristics of pregnant patients who experience conservative PPROM (gestational age <34 weeks) in Dr. Soetomo Hospital for period September 2017 to September 2019.

\section{Specific Purpose}

Describes pregnant women with PPROM receiving conservative therapy and the output of infant from September 2017 to September 2019. Trying to find PPROM with gestational age <34 weeks under conservative therapy can reach until > 34 weeks of gestational age.

\section{Benefit}

Providing information about the characteristics of pregnancy with PPROM ( $<34$ weeks of gestational age) to patients who visited during the period September 2017 to September 2019 at Dr. Soetomo Hospital in Surabaya

This research can be used as a reference to improve the quality of maternal services for the management of pregnancy with PPROM

\section{Methods}

A Retrospective Descriptive Study

- Using Delivery ward's register book, Medical Records and Morning Report's file for period September 2017 to September 2019

\section{Inclusion Criteria}

All cases of PPROM ( $<34$ weeks of gestational age) that occurred at Dr. Soetomo Hospital in Surabaya from September 2017 to September 2019

\section{Exclusion Criteria}

All cases of PPROM at $>34$ weeks of gestational age.

\section{Result}

Table 1. Incidence of PPROM Dr. Soetomo Hospital in September 2017 to September 2019

\begin{tabular}{lcc}
\hline Characteristic & Total & \% \\
\hline $\mathbf{2 0 1 8}$ & 93 & $3,6 \%$ \\
$\mathbf{2 0 1 9}$ & 82 & $3,2 \%$ \\
\hline
\end{tabular}

Table 2. Distribution of KPP Preterm patients at RSUD Dr. Soetomo based on the type of reference for the period September 2017 to September 2019

\begin{tabular}{lcc}
\hline Referral Type & Total & \% \\
\hline NBC & 152 & $86,9 \%$ \\
BC & 23 & $13,1 \%$ \\
\hline
\end{tabular}

Table 3. Distribution of PPROM patients at Dr. Soetomo Hospital based on age from September 2017 to September 2019

\begin{tabular}{lcc}
\hline Age & Total & $\%$ \\
\hline Year 2018 & & \\
$<20$ th & 9 & $1,5 \%$ \\
$21-35$ th & 64 & $10,6 \%$ \\
$>35$ th & 20 & $3,32 \%$ \\
\hline Year 2019 & & \\
\hline
\end{tabular}




\begin{tabular}{lll}
\hline$<20$ th & 11 & $2,11 \%$ \\
$21-35$ th & 59 & $11,3 \%$ \\
$>35$ th & 12 & $2,3 \%$ \\
\hline
\end{tabular}

Table 4. Distribution of PPROM patients at Dr. Soetomo Hospital based on parity for the period September 2017 to September 2019

\begin{tabular}{lrcc}
\hline Paritas & Total & $\%$ & $\begin{array}{l}\text { Preterm } \\
\text { Cases/2 years }\end{array}$ \\
\hline Primipara & 76 & $43 \%$ & $9,28 \%$ \\
Multipara & 99 & $57 \%$ & $5,06 \%$
\end{tabular}

Table 5. Distribution of PPROM patients at Dr. Soetomo Hospital based on the gestational age when rupture of membrane first occurred for the period September 2017 to September 2019

\begin{tabular}{lcc}
\hline PPROM occur & Total & \% \\
\hline$<26$ week & 30 & $17,1 \%$ \\
26-30 week & 52 & $29,7 \%$ \\
31-34 week & 93 & $53,1 \%$ \\
\hline
\end{tabular}

Table 6. Distribution of PPROM patients at RSUD Dr. Soetomo who received Lung Maturation from September 2017 to September 2019

\begin{tabular}{lrrr}
\hline $\begin{array}{l}\text { Lung } \\
\text { Maturation }\end{array}$ & Total & $\%$ & \\
\hline & 126 & & $72 \%$ \\
\hline
\end{tabular}

Table 7. Distribution of patients with PPROM Dr. Soetomo Hospital based on risk factors for PPROM from September 2017 to September 2019

\begin{tabular}{lcc}
\hline Risk Factor & Total & $\begin{array}{l}\text { \% from } \\
\text { preterm } \\
\text { cases/2 years }\end{array}$ \\
\hline Gemeli & 17 & $23,6 \%$ \\
Underweight & 1 & $3,1 \%$ \\
HbsAg & 6 & $7,5 \%$ \\
HIV & 4 & $7 \%$ \\
Anemia & 46 & $10,3 \%$ \\
Obesity & 40 & $5,2 \%$ \\
Pragestasional Diabetes & 4 & $7,4 \%$ \\
Gestasional Diabetes & 2 & $2,6 \%$ \\
Preeklampsia & 10 & $7,9 \%$ \\
Severe Preeklampsia & 16 & $2,2 \%$ \\
\hline
\end{tabular}

Table 8. Distribution of PPROM patients at Dr. Soetomo Hospital who received Conservative treatment from September 2017 to September 2019

\begin{tabular}{lcc}
\hline Conservative & Total & $\%$ \\
\hline Amniopatch & 5 & $26 \%$ \\
Amnioinfusi & 14 & $74 \%$ \\
\hline
\end{tabular}

Table 9. Distribution of conservative PPROM patients with Amnioinfusion Dr. Soetomo in September 2017 to September 2019

\begin{tabular}{|c|c|c|c|c|c|c|c|}
\hline No & Name & Parity & $\begin{array}{l}\text { Gestational } \\
\text { Age }\end{array}$ & $\begin{array}{l}\text { Baby } \\
\text { gender }\end{array}$ & $\begin{array}{l}\text { Birth } \\
\text { Weight }\end{array}$ & $\begin{array}{l}\text { Apgar } \\
\text { score }\end{array}$ & Breathing \\
\hline 1. & LIS & Primi & 24/25 week & $\mathrm{P}$ & $630 \mathrm{~g}$ & $3-5$ & CPAP \\
\hline 2. & WIN & Primi & 24/25 week & $\mathrm{L}$ & $550 \mathrm{~g}$ & 0 & Died \\
\hline 3. & TIK & Gravida 2 & 26/27 week & $\mathrm{L}$ & $800 \mathrm{~g}$ & $1-3-5$ & Died \\
\hline 4. & SIH & Primi & $27 / 28$ week & $\mathrm{L}$ & $1300 \mathrm{~g}$ & $1-0$ & Died \\
\hline 5. & WAH & Gravida 2 & 24/25 week & $\mathrm{L}$ & $600 \mathrm{~g}$ & $3-5-7$ & CPAP \\
\hline 6. & PUT & Primi & 23/24 week & $\mathrm{L} / \mathrm{L}$ & $540 \mathrm{~g} / 500 \mathrm{~g}$ & $1-0 / 0$ & Died \\
\hline 7. & LIS & Primi & 28 week & $\mathrm{L}$ & $950 \mathrm{~g}$ & $1-1-3-5$ & PCV \\
\hline 8. & HIL & Primi & 21/22 week & $\begin{array}{l}\text { Hard to tio } \\
\text { evaluate }\end{array}$ & $500 \mathrm{~g}$ & $1-1-0$ & \\
\hline 9. & RAF & Gravida 2 & 29/30 week & $\mathrm{P}$ & $1200 \mathrm{~g}$ & $5-6$ & CPAP \\
\hline 10. & DIA & Gravida 4 & $24 / 25$ week & $\mathrm{L}$ & $950 \mathrm{~g}$ & $1-1-3$ & Ventilator \\
\hline 11. & RAK & Primi & $31 / 32$ week & $\mathrm{P}$ & $1000 \mathrm{~g}$ & $7-8$ & CPAP \\
\hline 12. & DEL & Gravida 3 & 30/31 week & $\mathrm{P}$ & $1390 \mathrm{~g}$ & $5-7$ & CPAP \\
\hline
\end{tabular}

Table 10. Distribution of conservative PPROM patients with Amniopatch Dr. Soetomo Hospital in September 2017 to September 2019 


\begin{tabular}{|c|c|c|c|c|c|c|c|c|}
\hline No & Name & Parity & $\begin{array}{l}\text { Gestational } \\
\text { Age }\end{array}$ & $\begin{array}{l}\text { Baby } \\
\text { Gender }\end{array}$ & $\begin{array}{l}\text { Birth } \\
\text { Weight }\end{array}$ & $\begin{array}{l}\text { Apgar } \\
\text { Score }\end{array}$ & \multicolumn{2}{|c|}{ Breathing } \\
\hline 1. & EKA & Gravida 4 & $33 / 34$ week & $\mathrm{P}$ & $2000 \mathrm{~g}$ & $5-6$ & \multicolumn{2}{|c|}{ Spontaneous } \\
\hline 2. & DIP & Primi & 27/28 week & $\mathrm{P}$ & $1300 \mathrm{~g}$ & $5-7$ & \multicolumn{2}{|c|}{ CPAP } \\
\hline 3. & DEV & Primi & 30/31 week & $\mathrm{L}$ & $1500 \mathrm{~g}$ & $6-7$ & \multicolumn{2}{|c|}{ CPAP } \\
\hline 4. & TKW & Gravida 4 & 23/24 week & $\mathrm{L}$ & $500 \mathrm{~g}$ & 0 & \multicolumn{2}{|c|}{ Died } \\
\hline 5. & FIR & Gravida 3 & 30/31 week & $\mathrm{L}$ & $1000 \mathrm{~g}$ & $5-7$ & \multicolumn{2}{|c|}{ CPAP } \\
\hline \multirow{2}{*}{\multicolumn{5}{|c|}{$\begin{array}{l}\text { Table 11. Distribution of Mode of Delivery for } \\
\text { Patients with PPROM Dr. Soetomo Hospital } \\
\text { in September } 2017 \text { to September } 2019\end{array}$}} & \multirow{2}{*}{\multicolumn{2}{|c|}{$\begin{array}{l}1000-2500 \mathrm{~g} \\
<1000 \mathrm{~g}\end{array}$}} & 110 & $73 \%$ \\
\hline & & & & & & & 34 & $23 \%$ \\
\hline
\end{tabular}

\begin{tabular}{ccc}
\hline Mode of Delivery & Total & $\%$ \\
\hline Vaginal Delivery & 92 & $61 \%$ \\
Cesarean Section & 60 & $39 \%$ \\
\hline
\end{tabular}

Table 12. Distribution of Caesarean Section Indication in Patients with PPROM Dr. Soetomo Hospital in September 2017 to September 2019

\begin{tabular}{lcc}
\hline CS Indication & Total & $\%$ \\
\hline Fetal Distress & 15 & $25 \%$ \\
Abnormal NST & 11 & $18 \%$ \\
Gemeli & 10 & $17 \%$ \\
BSC & 7 & $12 \%$ \\
Fever & 6 & $10 \%$ \\
Breech presentation & 3 & $5 \%$ \\
Severe Preeclampsia \& & 3 & $5 \%$ \\
Lung Oedema & 5 & $8 \%$ \\
\hline
\end{tabular}

Table 13. Baby Outcomes from PPROM at birth Dr. Soetomo in September 2017 to September 2019

\begin{tabular}{lcc}
\hline Outcome baby & Total & $\%$ \\
\hline Asfiksia (+) & 90 & $87 \%$ \\
Asfiksia (-) & 14 & $13 \%$ \\
\hline
\end{tabular}

Table 14. Distribution of baby outcomes from PPROM based on Birth Weight at Dr. Soetomo Hospital in September 2017 to September 2019

\begin{tabular}{lcc}
\hline Birth Weight & Total & $\%$ \\
\hline$>2500$ g & 6 & $4 \%$ \\
\hline
\end{tabular}

Table 15. Distribution on the Breathing Aid of PPROM's baby at birth in September 2017 to September 2019

\begin{tabular}{cc}
\hline Breathing Aid & Jumlah \\
\hline Spontaneous & 36 \\
O2 nasal & 13 \\
CPAP & 70 \\
Ventilator & 8 \\
Death & 38 \\
\hline
\end{tabular}

Table 16. Distribution the causes of infant mortality in PPROM Patients in September 2017 to September 2019

\begin{tabular}{lcc}
\hline Causes of death & total & $\%$ \\
\hline IUFD & 5 & $13 \%$ \\
RDS & 9 & $24 \%$ \\
Sepsis & 4 & $11 \%$ \\
Low Birth Weight & 1 & $3 \%$ \\
Severe Asfiksia & 19 & $50 \%$ \\
\hline
\end{tabular}

Table 17. Distribution the length of day in NICU among infants who died Dr. Soetomo Hospital in September 2017 to September 2019

\begin{tabular}{ccc}
\hline $\begin{array}{c}\text { The Length of } \\
\text { Day in NICU }\end{array}$ & Total & $\%$ \\
\hline < 24 hours & 14 & $37 \%$ \\
1-3 Day & 13 & $34 \%$ \\
4-7 Day & 3 & $8 \%$ \\
$>$ 7 Day & 3 & $8 \%$ \\
\hline
\end{tabular}

Table 18. Distribution of Survival babies receiving Amniopatch / Amniosynthesis Treatment for PPROM in September 2017 to September 2019

\begin{tabular}{|c|c|c|c|c|c|c|}
\hline No & Name & $\begin{array}{l}\text { Gestational } \\
\text { Age }\end{array}$ & $\begin{array}{l}\text { Conservative } \\
\text { Treatment }\end{array}$ & $\begin{array}{l}\text { Birth Weight/ } \\
\text { Apgar Score }\end{array}$ & Diagnosis & $\begin{array}{l}\text { Length of } \\
\text { Stay in } \\
\text { NICU }\end{array}$ \\
\hline 1. & EKA & $33 / 34$ week & Amniopatch & $2000 \mathrm{~g} / \mathrm{AS} 5-6$ & Bacterial Sepsis & 7 hari \\
\hline 2. & DEV & $33 / 34$ week & Amniopatch & $1500 \mathrm{~g} / \mathrm{AS} 5-7$ & BBLR, Bacterial Sepsis & 22 hari \\
\hline 3. & DEL & 30/31 week & Amnioinfusi & 1390/AS 5-7 & Anemia,Trombositopenia, BBLR & 25 hari \\
\hline
\end{tabular}




\section{Discussion}

The sample in this study was dominated by mothers in reproductive age, mostly the age of 21-35 years from September 2017 to September 2019. The results of this study are in accordance with research conducted by Tengku et al which stated that the case of PPROM in Prof. Dr. R. D. Kandou Menado in 2018 mostly aged 20-35 years. This is supported by another study conducted in India by Mohan et al, which states that most cases are in the 20-30th age of mothers. (Mohan et al., 2017)

The number of PPROM patients with gestational age <34 weeks from September 2017 to September 2019 were 175 patients, where NBC cases were $86.9 \%$ and BC cases were $13.1 \%$. These results are consistent with the research conducted by Khade et al in India where Non Booked Cases were bigger than Booked Cases. This is due to inadequate Antenatal care which results in a lack of identification of risk factors in early pregnancy.

In the PPROM cases from September 2017 to September 2019, there were more patients with multiparous (99 patients) than mothers with primiparous (76 patients). The study conducted by Khade et al showed the same result, mostly multiparous (52\%) were higher than primiparous $(48 \%)$. The incidence of PPROM was found in many multiparous mothers because frequent pregnancies can affect embryogenesis so that the formed amniotic membrane will be thinner and prone to rupture, and amniotic infection is easier to occur due to damage to the cervical structure in previous deliveries. Distribution of PPROM patients with Gemeli pregnancy for the period of September 2017 to September 2019, there were 17 patients, which if calculated as a whole with the number of preterm deliveries, $23.6 \%$ of preterm deliveries were obtained. Whereas in the case of PPROM with underweight mothers, there was only 1 patient during a 2 year period. There were 6 patients with HBsAg and 4 patients with HIV. The results showed that a total of $7 \%$ of HIV patients with preterm KPP. This is consistent with a study conducted by Chidebere et al in KwaZuluNatal, South Africa, which found that the incidence of preterm KPP was not high in patients with HIV (Chidebere, 2017).

PPROM before 26 weeks can delay lung development and can cause pulmonary hypoplasia (Van Teeffelen, 2014). Pulmonary hypoplasia is a term to describe an altered pulmonary development characterised by a reduction in the number of pulmonary alveoli or in bronchial branching. In fetal lung development a critical interval, the canalicular phase, exists between 16 and 28 weeks gestation. Gestational age at rupture of membranes has been shown to be inversely related to the risk of pulmonary hypoplasia. (Porat et al., 2012). In this study, the distribution of PPROM patients who received lung maturation for preventing pulmonary hypoplasia was $72 \%$, while the remaining $28 \%$ did not get lung maturation.

Type of delivery for PPROM cases was vaginal delivery as much as $60 \%$ while $40 \%$ for cesarean section. Indications for vaginal delivery include fetal distress $25 \%$, abnormal NST 18\%, gemeli 17\%, BSC $12 \%$, febris $10 \%$, pulmonary edema $5 \%$ and breech presentation 5\%. The outcome distribution of PPROM infants born with asphyxia at birth was $87 \%$. Weight of

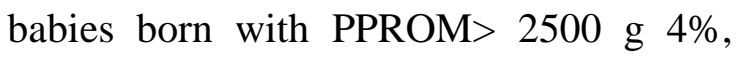
$1000-2500 \mathrm{~g} 73 \%$ and $<1000 \mathrm{~g} \mathrm{23 \%}$. The condition of the babies at birth with spontaneous breathing was 36 babies, nasal O2 was 13 babies and CPAP was 70 babies. The causes of death for preterm KPP babies 
included RDS 9 babies, Sepsis 4 babies and severe asphyxia 19 babies.

The length of NICU care for infants who died with KPP Preterm mothers was <24 hours for 15 babies, 1-3 days 13 babies, 4-7 days 3 babies,> 7 days 3 babies and 5 fetuses were IUFD. Amnioinfusion might improve fetal outcome by preventing pulmonary hypoplasia (Hofmeyr, 2014), by preventing neurological complications, increasing time to delivery interval, and improving fetal biophysical profile through prevention of umbilical cord compression. It also might prevent fetal deformity (Porat et al., 2012). 12 patients with PPROM in this study received amnioinfusion while 5 patients with amniopatch, The outcome of infants from this conservative PPROM who were treated with amniopatch or amnioinfusion obtained 6 babies died at birth, 8 babies with CPAP breath support, 1 baby with PCV breath support, 1 baby with ventilator and 1 infant spontaneously breathed. A total of 3 babies were outpatient after treatment for a maximum of \pm 25 days.

\section{Conclusion}

Premature infant puts immense burden on the economy and health care resources of the country. Therefore, management of PPROM requires accurate diagnosis and evaluation of the risk factors and benefits of continued pregnancy or expeditious delivery.

\section{References}

Chidebere, E., Onwughara, Moodley, D., Valashiya, N., Sebitloane, M. 2017. Preterm Prelabour Rupture Of Membranes (PPROM) And Pregnancy Outcomes In Association With HIV-1 Infection In Kwazulu-Natal, South Africa. BMC Pregnancy and Childbirth 20:204. Doi 10.1186/s12884-02002911-1.
Cunningham, F. 2014. Abnormal Labour. Williams Obstetrics. New York: McGraw-Hill Education. pp. Chapter 23(pg176).

Hofmeyr, G. J., Eke, A. C., \& Lawrie, T. A. 2014. Amnioinfusion For Thirs Trimester Preterm Premature Rupture Of Membranes. Chocrane Database Systematic Reviews doi:10.1002/ 14651858.cd000942.pub3

Medina, Tanya $\mathrm{M}$ and Hill, D. Ashley. 2006. Preterm Premature Rupture of Membrane: Diagnosis and Management. American Family Physician 73(4): 659664

Mohan, SS., Thippeveeranna, S., Naorem, N., Singh, Laiphrakpam, RS. 2017. Analysis of risk factors, maternal and fetal outcome of spontaneous preterm premature rupture of membranes: a cross sectional study. IJRCOG. 2017. 6(2);2327.DOI:http://dx.doi.org/10.18203/2320 $-1770 . i j r \operatorname{cog} 20173623$

Okeke, TC., Enwereji, JO., Okoro, OS., Adiri, CO., Ezugwu, EC., Agu, PU. 2014. The Incidence and Management Outcome of Preterm Premature Rupture of Membranes (PPROM) in a Tertiary Hospital in Nigeria. American Journal of Clinical Medicine Research 2(1): 14-17

Porat, S., Amsalem, H., Shah, PS., Murphy, KE. 2012. Transabdominal amnioinfusion for preterm premature rupture of membranes: a systematic review and metaanalysis of randomized and observational studies. Am J Obstet Gynecol 207(5):393.e1-11. DOI: 10.1016/j.ajog.2012.08.003. Epub 2012 Aug 10. PMID: 22999157.

Shailja, Dayal and Peter L. Hong. 2020. Premature Rupture of Membranes. https://www.ncbi.nlm.nih.gov/books/N BK532888/ Accessed at Jan 26, 2021

Teuku, IS., Hermie, M., Tendean, M., John, JE., Wantania. 2020. Gambaran Kejadian Ketuban Pecah Dini (KPD) di RSUP Prof. Dr. R.D. Kandou Manado 
Tahun 2018. Medical Scope Journal (MSJ) 1(2):24-29. DOI:https://doi.org/ 10.35790/msj.1.2.2020

Van Teeffelen, Augustinus., van der Ham, David P., Willekes, Christine., Al Nasiry, Salwan., Nijhuis, Jan G., van Kuijk, Sander., Pajkrt, Eva. 2014. Midtrimester Pretem Prelabour Rupture Of Membranes (PPROM): Expectant Management Or Amnioinfusion For Imporving Perinatal Outcomes (PPROMEXIL - III trial). BMC Pregnancy and Childbirth 14 (1) doi:10.1186/1471-2393-14-128 